\title{
THE IMPLEMENTATION OF TEAM GAME TOURNAMENT (TGT) TYPE COOPERATIVE LEARNING MODEL TO IMPROVE LEARNING MOTIVATION AND LEARNING ACHIEVEMENT
}

\author{
IMPLEMENTASI MODEL PEMBELAJARAN KOOPERATIF TIPE TEAM GAME \\ TOURNAMENT UNTUK MENINGKATKAN MOTIVASI BELAJAR DAN HASIL \\ BELAJAR
}

By : Nurul Hidayah

Accounting Education Study Program Yogyakarta State University nurulhidayah3795@gmail.com

\section{Abdullah Taman}

Lecturer of Accounting Education Study Program Yogyakarta State University

\begin{abstract}
The objective of this research was improving learning motivation and learning achievement of XI Accounting 1 Students of SMK Negeri 1 Pengasih Academic Year 2016/2017 using Cooperative Learning Model Team Game Tournament (TGT) on the subject Accounting for Trading Company. This research was Classroom Action Research (CAR) collaborating with teacher in two cycle. Data collection technique used were questionnare, documentation, and test. Based on research result concluded that implementation of Cooperative Learning Model Team Games Tournament (TGT) could improve Learning Motivation and Learning Achievement of XI Accounting 1 student of SMK 1 Pengasih Academic Year 2016/2017 evidenced by improvement of motivation score and achievement score. Motivation questionnare result shown improvement of students' learning motivation improved to $5.97 \%$ from cycle I of $72.41 \%$ increased to $78.13 \%$ in cycle II. Improvement of Accounting Learning Achievement calculated from the average score increase of $23.78 \%$ in first cycle and increased of $19.61 \%$ in the second cycle.
\end{abstract}

Keywords: Cooperative Learning, Team Game Tournament, Learning Motivation, Learning Achievement

\begin{abstract}
Abstrak
Tujuan dari penelitian ini adalah meningkatkan motivasi belajar dan hasil belajar siswa kelas XI Akuntansi 1 SMK Negeri 1 Pengasih Tahun Ajaran 2016/2017 menggunakan Model Pembelajaran Kooperatif Tipe Team Game Tournament (TGT) pada mata pelajaran Akuntansi Perusahaan Dagang. Penelitian ini merupakan Penelitian Tindakan Kelas yang dilaksanakan secara kolaboratif dengan guru mata pelajaran akuntansi selama dua siklus. Subjek penelitian ini adalah siswa kelas XI Akuntansi 1 SMK Negeri 1 Pengasih Tahun Ajaran 2016/2017. Teknik pengumpulan data yang digunakan adalah angket, dokumentasi, dan tes. Berdasarkan hasil penelitian disimpulkan bahwa penerapan Model Pembelajaran Kooperatif Tipe Team Game Tournament (TGT) dapat meningkatkan motivasi belajar dan hasil belajar Akuntansi siswa kelas XI Akuntansi 1 SMK Negeri 1 Pengasih Tahun Ajaran 2016/2017 dibuktikan dengan peningkatan skor motivasi belajar dan hasil belajar akuntansi. Hasil angket motivasi belajar menunjukkan peningkatan sebesar 5,97\% dari rata-rata skor siklus I yaitu 72,41\% meningkat menjadi 78,13\% pada siklus II. Peningkatan hasil belajar akuntansi dihitung dari rata-rata meningkat sebesar 23,78\% pada siklus I dan meningkat sebesar 19,61\% pada siklus II.
\end{abstract}

Kata Kunci: Pembelajaran Kooperatif, Team Game Tournament, Motivasi Belajar, Hasil Belajar 


\section{INRODUCTION}

Achievement indicators of human resources management in a country is education. Therefore, developing and promoting education is a must for a country. The initial step to develop students potential optimally is design learning activities atmosphere that are exciting, interactive, and attractive, as well as balanced with attention to the character of the students. In addition, education have to involves active participation of each student, education is essentially provide a learning experience to develop the potential of students, through a process of interaction between students and students, students and teachers or students in the environment. (Wina Sanjaya, 2012:178)

Students can obtain learning experience of interaction in the school then forms a potential in their self which can be known through the evaluation of learning achievement by an educator. In the same class, learning results obtained by each students will not be the same as others, it is influenced by internal factors and external factors. Internal factors are factors that exist in individuals who are learning, while external factors are factors that are outside the individual (Slameto, 2010:54).

One of internal psychological factors in the learning process that affect student learning is motivation. In a learning process motivation is a very important aspect for students. According to Wina Sanjaya (2012: 135), without motivation, students will not have the willingness to learn. Therefore, encourage motivation is one of roles and duties of teachers in each of learning process. Internal psychological conditions of the student certainly will affect the achievement of learning objectives. Therefore, it needs a solution to increase students' motivation in accounting learning so the motivation will be positively correlated with student learning achievement.

Motivation can be divided into intrinsic motivation and extrinsic motivation (Sardiman., 2011:90). Intrinsic motivation is the motives that do not need to be stimulated from the outside. While the extrinsic motivation is motives that have to stimulated from the outside. Teacher as a mediator in an accounting learning process can increase extrinsic motivation by providing appropriate accounting learning and the creation of a pleasant learning atmosphere, so students can be actively involved in the learning process. In this case, the need for an innovative approach of different strategies for the learning process to be effective and enjoyable, so learning objectives can be achieved. Therefore, teacher have to develop a learning model that can improve students' motivation.

According to Agus Suprijono (2013:45), learning model is the foundation of learning practices in the theory of educational psychology and learning theory are designed based on analysis of the implementation of curriculum and its implications on the operational level in the class. The function of learning model as a guideline for learning designers and teachers who plan learning activities. Selection of appropriate learning models is one of the factors that support the completeness of learning implementation in the class, so teachers need to pay attention to the learning model in accordance with the conditions of students and curriculum. Learning model that involves students actively become a large selection of learning model that supports 2013 Curriculum (K13) which has a principle of learning centered on the learner, develop students' creativity, creating fun and challenging conditions, developing a variety of capabilities that charged the value, provides a diverse learning experience and learn through doing (learning by doing) (Wina Sanjaya, 2012: 132).

One of learning models that was developed recently is cooperative learning model. The core of a cooperative learning is students will sit together in groups to master the material which presented by the teacher. One of the benefits of cooperative learning model is able to increase academic achievement at the same time as increasing 
social capabilities include developing a sense of self esteem, positive interpersonal relationships with others, developing skills to manage time, and a positive attitude toward school (Wina Sanjaya, 2012:250). In this case, the model of cooperative learning allows educators to maximize the improvement of students' motivation and learning achievement through cooperation on each students. Cooperation will eanhace students' willingness to study harder than learn individually, it will effect on students' motivation then followed by higher achievement.

The same problem was faced by XI Accounting 1 Students of SMK Negeri 1 Pengasih. Based on interviews and observations in $\mathrm{X}$ Accounting 1 class, it appeared that student motivation is low because teachers deliver the material using the same method continuously, students became bored and did not have the spirit of learning. As a result, students done other activities such as chatting and playing mobile phones to overcome the boredom, it impacts on student learning achievement to be not optimal. From the data of daily test results of students in X Accounting 1 class, the result of the average grade obtained on the subjects of Accounting for Services Enterprise is 74,19 . The average value obtained by the students has not reached the criteria of minimum mastery specified by school is 78 and only $31.25 \%$ of the total 32 students who have reached the criteria of minimum mastery, 10 students have reached the criteria of minimum mastery while 22 students have not reached the criteria of minimum mastery.

Based on the problems that have been described, learning process at X Accounting 1 class need to use cooperative learning model that involves all students. Type of Cooperative Learning Models are Student Teams Achievement Divisions (STAD), Team Games Tournament (TGT), Team Assisted Individualization (TAI), Cooperative Integrated Reading and Composition (CIRC), and et.al. STAD using quiz individual score to earn team score, the differences with conventional model just on the accumulating of students' score to be team score. TGT using team game that need cooperation on each member to get higher team score, TAI based on individualization learning, it was like conventional learning model, and CIRC focus on comprehensive reading, so CIRC was not suitable for Accounting subject that need more practices than reading the material. Among many existing choices in cooperative learning model, learning model of Team Games Tournament (TGT) could be a solution to the faced problems faced in the X Accounting 1 class and X Accounting 2 class especially in Accounting Subject.

Team Games Tournament (TGT) is one of learning model that packaged into fun game cooperation which can enhance students' learning activities both cognitive and psychomotor, enhance students' understanding of the material and increase learning motivation. In this model, students are expected to participate actively, creatively, more leverage in understanding the material, increasing the percentage of completeness. Besides the implementation of cooperative learning model TGT can also provide new knowledge to the teachers about the learning model that can be applied in the classroom.

Based on the description that has been described above researcher trying to do a research entitled "The Implementation of Team Games Tournament (TGT) Type Cooperative Learning Model to Improve Learning Motivation and Learning Achievement of XI Accounting 1 Students of SMK Negeri 1 Pengasih Academic Year 2016/2017".

\section{RESEARCH METHOD}

This research was classroom action research collaborated with accounting teacher. According to Kunandar (2011: 44) Classroom Action Research is an action research conducted by teacher as well as researcher in class or jointly with others 
(collaboration) by designing, implementing, and reflecting the action collaboratively and participatively, that had aims to repair or improve the quality of the learning process in the class through an action (treatment) in a certain cycle. This classroom was conducted at SMK Negeri 1 Pengasih from July to September 2016.

Data was collected as much as two cycles with one meeting in each cycle. The research subject was 32 students of XI Accounting 1. While the object of research was learning motivation and learning achievement. The research step was: planning step was consist of arranging lesson plan, group divison, media, field notes, question card for the game, game procedure, and team assesment. Then, action step was learning activities using Team Game Tournament as follows: pre test, material explanation, group discussion, team game tournament, post test, and closed by distribution of motivation questionnare and reflection. The third step was observation, it was made during learning process by recording the events using field notes. The last step of first cycle was reflection, it was conducted to determine weaknesses during the implementation of fisrt cycle. For second cycle, the stage was similar to the first cycle, but there should be improvements as a result of first cycle reflection.

Data collection techniques in this study were questionnare to collect motivation data, docummentation using field notes to record learning activities, and test to collect achievement data. The formula to calculate students' motivation percentage was

Student Motivation Score Maximum Score $>100 \%$

The formula to calculate avaerage score of students achievement was:

Mean Formula $=M e=\frac{\sum x i}{N}$

Information :

Me : Average (mean)

$\sum x i \quad$ : Total all grades

$N \quad$ : The number of individuals
This research said to be succes if there are improvement of learning motivation both individually and goup average score after the implementation of Cooperative Learning Model Team Games Tournament and average motivation score at least $75 \%$. Students also have to reached the criteria of minimum mastery 78 at least $75 \%$ of the total number of XI Accounting 1 students.

\section{RESEARCH RESULT T AND DISCUSSION}

Researcher conducted observations before taking action on the research subject by conducting interviews and observations in the classroom. From interviews and observations there were some problems in accounting learning in class XI Accounting 1, are as follows: Students motivation wass low as indicated by the questionnaire and observations in the classroom. The observations made by researcher on 20 March 2016 and 22 February 2016 indicates that many students who still have low motivation in the learning process. This is evidenced by the results of questionnaires motivation to learn accounting of XI Accounting 1 students were distributed on 20 July 2016 shows the average motivation score only $60.12 \%$. Of the average, it can be concluded that the learning motivation of class XI Accounting 1 is low and needs to be given action to increase student motivation to learn accounting.

Learning achievement of class XI Accounting 1 indicates that $31.25 \%$ of the students have not been able to reach KKM (Kriteria Ketuntasan Minimal) has been set by the school (78). It shows that the implementation of accounting learning in the classroom is not maximized. The learning environment at the time of observation and during the action also has the same characteristics with the same class.

From some of these problems, it can be concluded that accounting learning activities in class XI Accounting 1 SMK Negeri 1 Pengasih require an action to improve student learning achievement. The way proposed by 
researcher to improve learning motivation and learning achievement of accounting is the implementation of Cooperative Learning Model Team Games Tournament (TGT). Hopefully, the application of this model able to improve learning motivation and learning achievement of XI Accounting 1 students SMK Negeri 1 Pengasih.

Cooperative Learning Model Team Games Tournament (TGT) first cycle was conducted for 4 hours of lessons in one meeting, on 5 September 2016 on the topic The Use of Ledger, Journal, and Subsidiary Ledger.

Planning step of first cycle was arranging Lesson Plan of The Use of Ledger, Journal, and Subsidiary Ledger based on the existing syllabus, making action implementation schedule as a reference, arranging learning materials, making learning media devices using power point that is used to explain the learning materials, making pre-test and post test used to measure learning achievement, making heterogeneous group divisions used for group discussion stage. A heterogeneous group comprised of four groups where each group consisted of 8 students. Each group consisted of students with the category of High, Medium I, Medium II, and Low. A heterogeneous group for the first cycle and the second cycle consists of the same students. The group was formed based on the score of the initial observations. These groupings are based on the ability of students so one group consist of various students' abilities. Foloowed by making tournament games procedure used in the tournament, making question cards that will be used at tournament stage, preparing the equipment used in games tournament, creating assessment form used during the tournament, making field notes format used to record the events that occurred during the learning process takes place, making questionnaire used to measure students' motivation, and setting up reward that is used as award for the best team.

Team game tournament procedure are as follows: all members of the group marched on the sidelines of tables row, inter-group competing to answer the question card that has been provided for each group, starting from the first sequence alternately take a card questions, then write the answers on the board. Students who have difficulty on answering assisted by friends behind. When all groups finished answering questions, students and teachers together correcting answers of each group. Score determined by speed to answer questions and sum of correct answer.

The first cycle conducted on Monday, 29 August 2016 as long as 4 lesson hours, there are from sixth hour till ninth hour. Learning activities in the first cycle were pre test, material explanation, group discussion, team game tournament, post test, and questionnare filiing. Observation were made during the learning process using Cooperative Learning Model Team Games Tournament.

Researcher using field notes to observe and record the things that could not be measured through questionnaires and tests during the learning process. Researcher assisted by teachers in the learning process observation. Questionnaires were used to measure accounting learning motivation while tests were used to measure accounting learning achievement consisting of pre-test and post test.

From the results of first cycle there are several obstacles in the implementation of Team Game Tournament. The first was, division of the group and transfer seating is reducing time of tournament game, and the second was conditions of narrow class created group rows into irregular when the game takes place. So, efforts to improve the application of Cooperative Learning Model Team Games Tournament in class XI Accounting 1 are as follows: using the same group for the second cycle so that students have to sit with members of the group when the class starts so it will not take time for other learning activities. And change the position of desks and chairs before classes begin in the morning so that provided a broader space for the game. 
After finishing cycle I stages, researcher do next cycle with the same step as cycle I. Basically, the planning done at the second cycle was not much different from planning in the first cycle, especially in terms of enforcement procedure. The difference is the planning done at the second cycle is done based on the evaluation and reflection from the implementation of cycle I. It was purposed as an improvement action in the first cycle so the weakness in the first cycle does not occurred again in the second cycle.

The second cycle conducted on Monday, 5 September 2016 as long as 4 lesson hours, there are from sixth hour till ninth hour in the topic of Bussiness Condition of Trading Company. Learning activities in the second cycle were pre test, material explanation, group discussion, team game tournament, post test, and closed by filling questionnare.

The learning process of Team Games Tournament (TGT) on the second cycle showed satisfactory results and have reached the criteria that have been set. It is evident from the learning motivation and learning achievement has achieved the minimum criteria that have been set. The results of the second cycle is described as follows: Data shows that the average score of students' motivation on the second cycle was $77.24 \%$ while the motivation scores of students in the first cycle is $71.72 \%$, thus there is an increase of $5.97 \%$ from the first cycle to the second cycle. In general it can be concluded that the implementation of Cooperative Learning
Model Team Games Tournament (TGT) successfully increase accounting learning motivation.

Accounting learning achievement achieved by students in the cognitive domain after execution of the learning Cooperative Learning Model Team Games Tournament on the second cycle showed good results and achieving targets marked by an increase from pre-test to post-test and an increase of mastery learning in class XI Accounting 1. This is indicated by the average score of pre test of 75.42 and the average score of post test of 90.21 , an increase of $19.61 \%$. While the number of students who completed the pretest reached $56.25 \%$ and the number of students who completed the post test reached $93.75 \%$. Thus it can be concluded that the implementation of Cooperative Learning Model Team Games Tournament (TGT) has succeeded in improving learning achievement in the cognitive of accounting.

\section{Improvement of Learning Motivation}

Based on learning motivation questionnaire data of pre-cycle, the first cycle and the second cycle can be seen that an increase in average scores of learning motivation from the pre cycle to cycle I and cycle I to cycle II. The success rate of Cooperative Learning Model Implementation Team Games Tournament to improve learning motivation is presented in the table below:

Table 1. Comparison of Motivation Score on Pre Cycle to Cycle I

\begin{tabular}{|c|l|c|c|c|c|}
\hline \multirow{2}{*}{ No. } & \multicolumn{1}{|c|}{ Indicator } & Pre & \multirow{2}{*}{ Cycle I } & \multicolumn{2}{c|}{ Improvement } \\
\cline { 5 - 6 } & & Cybsolut & Relative \\
\hline 1 & Doing the task diligently & $57,29 \%$ & $71,61 \%$ & $10,67 \%$ & $18,62 \%$ \\
\hline 2 & Doing the task frequently & $63,36 \%$ & $78,91 \%$ & $15,55 \%$ & $24,54 \%$ \\
\hline 3 & Showing the interest in a subject & $63,67 \%$ & $76,95 \%$ & $13,28 \%$ & $20,86 \%$ \\
\hline 4 & Prefers to work alone or in group & $59,11 \%$ & $67,71 \%$ & $8,5 \%$ & $14,38 \%$ \\
\hline 5 & Boring with the routine tasks & $67,19 \%$ & $78,39 \%$ & $11,2 \%$ & $16,67 \%$ \\
\hline 6 & Can hold their argument & $60,94 \%$ & $68,49 \%$ & $7,55 \%$ & $12,39 \%$ \\
\hline 7 & Hard to let the things that they believed & $50,78 \%$ & $60,68 \%$ & $9,9 \%$ & $19,50 \%$ \\
\hline 8 & Glad to find and solve problems & $56,64 \%$ & $58,36 \%$ & $1,72 \%$ & $3,04 \%$ \\
\hline \multicolumn{2}{r}{ Average } & $60,12 \%$ & $71,27 \%$ & $11,15 \%$ & $18,55 \%$ \\
\hline
\end{tabular}


Source: Primary data are processed

Table 2. Comparison of Motivation Score on Cycle I to Cycle II

\begin{tabular}{|c|l|c|c|c|c|}
\hline \multirow{2}{*}{ No. Indicator } & \multirow{2}{*}{ Cycle I } & \multirow{2}{*}{ Cycle II } & \multicolumn{2}{c|}{ Improvement } \\
\cline { 5 - 6 } & & & Absolut & Relative \\
\hline 1 & Doing the task diligently & $71,61 \%$ & $76,82 \%$ & $5,21 \%$ & $7,27 \%$ \\
\hline 2 & Doing the task frequently & $78,91 \%$ & $85,94 \%$ & $7,03 \%$ & $8,91 \%$ \\
\hline 3 & Showing the interest in a subject & $76,95 \%$ & $80,08 \%$ & $3,13 \%$ & $4,07 \%$ \\
\hline 4 & Prefers to work alone or in group & $67,71 \%$ & $75,52 \%$ & $7,91 \%$ & $11,68 \%$ \\
\hline 5 & Boring with the routine tasks & $78,39 \%$ & $82,81 \%$ & $9,42 \%$ & $12,02 \%$ \\
\hline 6 & Can hold their argument & $68,49 \%$ & $75,26 \%$ & $6,77 \%$ & $9,88 \%$ \\
\hline 7 & Hard to let the things that they believed & $60,68 \%$ & $70,05 \%$ & $9,37 \%$ & $15,44 \%$ \\
\hline 8 & Glad to find and solve problems & $58,36 \%$ & $69,92 \%$ & $11,56 \%$ & $19,81 \%$ \\
\hline \multicolumn{2}{r}{ Average } & $71,27 \%$ & $77,24 \%$ & $5,97 \%$ & $8,38 \%$ \\
\hline
\end{tabular}

Source: Primary data are processed

Motivation of students in indicator of doing the task diligently was improved, scores on the pre-cycle of $57.29 \%$ to $71.61 \%$ in the first cycle and then increased in the second cycle into $76.82 \%$. Improvement occurred because the teacher gaves different learning methods and atmosphere, which mades student learning while playing, and more comfortable in participating the learning so students be diligent and sincere in doing the task assigned by the teacher.

Motivation of students in indicator of doing the task frequently was increased, scores on the pre-cycle of $63.36 \%$ to $78.91 \%$ in the first cycle and then increased in the second cycle into $85.94 \%$. Improvement occurred due to group discussions which had a mutual relationship between the students of high category with lower category so students with lower categories will seek more resilient to face of the difficulties by discussing with students with high or medium category.

Motivation of students in the indicator showing the interest on a subject has increased, pre-cycle score of $63.67 \%$ to $76.95 \%$ in the first cycle and then increased in the second cycle into $80.08 \%$. Improvement occurred because the teachers always creating a pleasant learning conditions so students were happy to follow accounting subject which packed into the game.
Data from the questionnaire showed that learning motivation students' scores on the indicators prefers to work alone or in a group on the pre-cycle of $59.11 \%$ to $67.71 \%$ in the first cycle and then increased in the second cycle into $75.52 \%$. The improvement is due to the students realized the importance of working in a group and the benefits for themselves.

Student motivation scores on the indicators boring with routine tasks was increased, scores on the pre-cycle of $67.19 \%$ to $78.39 \%$ in the first cycle and then increased in the second cycle into $82.81 \%$. The Improvement occurred because teachers provided a variety of tasks and variety of learning models so students do not get bored in studying accounting trading company.

The improvement also occurred in the indicator of can hold their argument, scores on the pre-cycle of $60.94 \%$ to $68.49 \%$ in the first cycle and then increased in the second cycle into $75.26 \%$. The improvement was caused because there were discussion and presentation of the tournament game results was good so students were able to express their opinions either individually or in groups so that students have a basis for his opinion.

The improvement also occurred in the indicator hard to let the things that they believed, scores on the pre-cycle of $50.78 \%$ to $60.68 \%$ in the first cycle and then increased in the second cycle into $70.05 \%$. Improvement 
$66-75$

that happened can not be said as yet reached the maximum predetermined criteria because students had confidence in his opinion when in groups with other students who were high categories.

The improvement also occurred in the indicator glad to find and solve problems, scores on the pre-cycle of $56.64 \%$ to $58.36 \%$ in the first cycle and then increased in the second cycle into $69.92 \%$. The improvement was not maximum because they have not reached the predetermined criteria caused by students were only given a matter from the teacher and had no opportunity to look for other problems in addition to be done by the students themselves due to time limitation.
From the discussion above it could be concluded that cooperative learning model Team Games Tournament (TGT) is one of learning models that can improve student learning motivation in accounting subject

Improvement of Learning Achievement

In the implementation of accounting learning with Cooperative Learning Model TGT in the first cycle and the second cycle showed an improvement of accounting learning achievement particularly on cognitive. Here is the data learning achievement in the first cycle and the second cycle.

Table 3. Accounting Learning Achievement Recapitulation of Cycle I

\begin{tabular}{|c|c|c|c|c|c|}
\hline \multirow{2}{*}{$\begin{array}{c}\text { Score } \\
\text { Category }\end{array}$} & \multicolumn{2}{|c|}{ Pre Test } & \multicolumn{2}{c|}{ Post Test } & $\begin{array}{c}\text { Improvement on } \\
\text { average score }\end{array}$ \\
\cline { 2 - 6 } & Frequency & \% & Frequency & \% & \\
\hline $\mathrm{S} \geq 78$ & 13 & 40,63 & 27 & 84,38 & - \\
\hline $\mathrm{S}<78$ & 19 & 59,37 & 5 & 15,62 & - \\
\hline Total & 32 & 100 & 32 & 100 & \\
\hline Average & \multicolumn{2}{|c|}{68,33} & \multicolumn{2}{c|}{84,58} & $23,78 \%$ \\
\hline
\end{tabular}

Source: Primary data are processed

Table 4. Accounting Learning Achievement Recapitulation of Cycle II

\begin{tabular}{|c|c|c|c|c|c|}
\hline \multirow{2}{*}{$\begin{array}{c}\text { Score } \\
\text { Category }\end{array}$} & \multicolumn{2}{|c|}{ Pre Test } & \multicolumn{2}{c|}{ Post Test } & $\begin{array}{c}\text { Improvement on } \\
\text { average score }\end{array}$ \\
\cline { 2 - 6 } & Frequency & \% & Frequency & \% & \\
\hline $\mathrm{S} \geq 78$ & 18 & 56,25 & 30 & 93,75 & - \\
\hline $\mathrm{S}<78$ & 14 & 43,75 & 2 & 6,25 & - \\
\hline Total & 32 & 100 & 32 & 100 & $19,61 \%$ \\
\hline Average & \multicolumn{2}{|c|}{75,42} & 90,21 & \\
\hline
\end{tabular}

Source: Primary data are processed

When compared to the outline, the ratio of the average score of a class XI student of Accounting 1 of the first cycle and the second cycle are as follows:

Table 5. Comparison of Average Score from Cycle I to Cycle II

\begin{tabular}{|c|c|c|c|}
\hline \multirow{2}{*}{ Cycle } & \multicolumn{2}{|c|}{ Average Score } & Improvement \\
\cline { 2 - 4 } & Pre Test & Post Test & \\
\hline I & 68,63 & 84,58 & $23,78 \%$ \\
\hline II & 75,42 & 90,21 & $19,61 \%$ \\
\hline
\end{tabular}

Source: Primary data are processed 
Had been clearly shown in Table 5 if there is an increase in each cycle both in the first cycle and the second cycle. In the first cycle an increase of $23.78 \%$, while in the second cycle an increase of $19.61 \%$ from pretest to post-test. Decreased levels of improvement from pre-test to post-test in the second cycle because students are ready to follow the lessons when the second cycle begins with study first before following the learning so the score of pre test increased from the first cycle to the second cycle, it reinforces the conclusion of the previous variables, namely students' motivation. Students who have already motivated is already preparing himself to learn before the course.

From the accounting learning achievement observation can be concluded that the implementation of cooperative learning model type Team Games Tournament (TGT) can increase learning motivation and learning outcomes in class XI Accounting I SMK Negeri 1 Pengasih. Cooperative Learning Model Team Games Tournament involved the whole activity of students in solving problems individually or in groups. It showed everyone that learning should be active and have a high motivation. In the lack of activity and learning motivation, learning objectives will not be achieved, or in other words learning outcomes are not optimal. Therefore made an interesting learning process could create a conducive learning and can develop the potential of students.

Cooperative Learning Model Team Games Tournament (TGT) is external factors that affecting learning outcomes. This is in accordance with the opinion of Slameto (2010: 72) that the teaching method is a factor that affecting student learning outcomes. Therefore, teachers need to create a conducive classroom by applying activity-based learning model to foster students' motivation then students are comfortable in conducting learning activities so learning objectives planned by the teacher can be achieved.

\section{CONCLUSION \\ AND \\ RECOM- MENDATION}

Based on research results and discussion in Chapter IV concluded that the implementation of Cooperative Learning Model Team Games Tournament (TGT) could improve Learning Motivation and Learning Achievement in Accounting of XI Accounting 1 student of SMK 1 Pengasih Academic Year 2016/2017 evidenced by: Accounting Learning Motivation score obtained through the results of scoring questionnaire data was improved to $5.97 \%$ and improvement of individual motivation achievement scores amounted to $50 \%$. Accounting Learning Achievement in cognitive calculated from the average score of test result improved to $23.78 \%$ in first cycle and the second cycle was improved to $19.61 \%$, learning mastery also improved by $11.10 \%$ calculated from the mastery learning in post test cycle I of $84.38 \%$ increased in cycle II into $93.75 \%$.

Based on the conclusion teachers are expected to increase the confidence of the students against what they believes that is not easily affected by other students, and provides the opportunity for students to look for problems/questions by themself and then solve it. So, that students have the interest to solve the problem. Teacher also recommended to use variety of teaching methods in the future.

\section{REFERENCE}

Agus Suprijono. (2013). Cooperative Learning: Teori dan Aplikasi PAIKEM. Yogyakarta: Pustaka Belajar.

Anas Sudijono. (2006). Pengantar Evaluasi Pendidikan. Jakarta: Rajagrafindo Persada.

Dimyati dan Mudjiono. (2009). Belajar dan Pembelajaran. Jakarta: Rineka Cipta.

Kunandar. (2011). Langkah Mudah Penelitian Tindakan Kelas sebagai Pengembangan Profesi Guru. Jakarta: Rajawali Pers.

Sardiman. (2011). Interaksi dan Motivasi Belajar Mengajar. Jakarta: Rajawali Pers. 
$66-75$

Slameto. (2010). Belajar dan Faktor-faktor yang Mempengaruhinya. Jakarta: Rineka Cipta.

Sugiyono. (2015). Metode Penelitian Pendidikan. Bandung: Alfabeta.

Wina Sanjaya. (2012). Perencanaaan dan Desain Sistem Pembelajaran. Jakarta: Kencana Prenada Media Group.

(2012). Strategi

Pembelajaran Berorientasi Standar

Proses Pendidikan. Jakarta: Kencana Prenada Media Group. 